\title{
Strategi Political Public Relations Partai Solidaritas Indonesia wilayah Riau pada Pemilihan Legislatif tahun 2019
}

\author{
M.Tazri ${ }^{1}$, Desy Mairita ${ }^{2}$ \\ Prodi Hubungan Masyarakat, Universitas Muhammadiyah Riau \\ maztajri@gmail.com, desymairita80@gmail.com
}

\begin{abstract}
This research elaborates on the Political public relations strategy carried out by the novice politicians of the Indonesian Solidarity Party in the Riau region in the face of the $2019^{\text {th }}$ Legislative Elections. This research is important because the Indonesian Solidarity Party (PSI) is a new party and politicians who participate in political contestation are also novice politicians. This research is a descriptive qualitative research with case study method, data retrieval through the stages of observation, interviews and documentation. The results of this study reveal that the Political public relations strategy undertaken by PSI politicians is by combining image building, political branding and political marketing.
\end{abstract}

Keywords :Strategy, Politic, Public Relations

\begin{abstract}
Abstrak
Penelitian ini mengelaborasi tentang strategi Political public relations yang dilakukan politisi pemula Partai Solidaritas Indonesia wilayah Riau dalam menghadapi Pemilihan Legislatif tahun 2019. Penelitian ini penting karena Partai Solidaritas Indonesia (PSI) merupakan partai baru dan politisi yang mengikuti kontestasi politik juga merupakan politisi pemula. Penelitian ini adalah penelitian deskriptif kualitatif dengan metode studi kasus, pengambilan data melalui tahapan observasi, wawancara dan dokumentasi. Hasil penelitian ini mengungkapkan bahwa strategi Political public relationsyang dilakukan politisi PSI yaitu dengan mengkombinasikan pembentukan citra (image building), branding politik (political branding) dan pemasaran politik (marketing politic).
\end{abstract}

Kata kunci :Strategi, Politik, Public Relations

\section{A. PENDAhuluan}

Konsep demokrasi mengamanatkan bahwa kekuasaan tertinggi terletak pada rakyat. Lincoln menyebutkan bahwa demokrasi adalah suatu bentuk pemerintahan dimana kekuasaan politik tertinggi (supreme political authority) dan kedaulatan (sovereignty) ada ditangan rakyat (Mirriam, 2008). Demokrasi melahirkan konsep pemilihan umum (pemilu) dalam berbagai pemilihan pemimpin di Republik ini. Pemilihan umum (pemilu) merupakan mekanisme pemilihan pemimpin secara terbuka, bebas dan bertanggungjawab (UU No.7/2007). Pada bulan april tahun 2019, Indonesia menggelar pesta demokrasi akbar dimana dilaksanakannya Pemilihan Legislatif (pileg) dan Pemilihan Presiden (pilpres) secara bersamaan. Salah satu partai peserta pemillu yang merupakan partai baru adalah Partai Solidaritas Indonesia atau yang biasa disebut PSI. Partai PSI merupakan 1 dari 4 partai baru yang mengikuti pemilihan umum pada tahun 2019. Bukan hanya partai, seperangkat elemen termasuk kader-kader partai PSI adalah orang-orang baru yang berlum pernah terlibat di partai-partai lain sebelumnya. Sehingga, sebagai partai baru PSI dirasa memerlukan usaha lebih agar partai PSI dapat dikenal dan diterima publik dalam pemilihan ini.

\footnotetext{
${ }^{1}$ Dosen Prodi Hubungan Masyarakat, Universitas Muhammadiyah Riau

${ }^{2}$ Dosen Prodi Hubungan Masyarakat, Universitas Muhammadiyah Riau
} 
Mekanisme pemilu sering disebut dengan pemilihan langsung, dimana masyarakat pada saat pemilihan bisa menggunakan hak konstitusionalnya dalam menentukan pilihan terhadap salah satu kandidat pemimpinnya, baik itu eksekutif maupun legislatif. Dalam dinamika politik di Indonesia hari ini, sistem pemilihan langsung membuat kandidat mengeluarkan biaya ekstra untuk dikenal publik secara baik demi memenangkan kompetisi, biaya tersebut diantaranya meliputi biaya kampanye, biaya iklan, tim sukses, atau bahkan biaya untuk tim konsultan. Konsekuensinya adalah bahwa dinamika pemililhan langsung ini memaksa politisi untuk membangun citra. Politisi disibukkan dengan agenda politik yang hanya berputar pada kondisi membangun citra individu dan kelompok demi mendapatkan perhatian publik dalam konstestasi politik. Dengan demikian, melihat bagaimana kondisi sosial masyarakat dan bagaimana panggung politik hari ini, sangat wajar ketika pembentukan citra positif menjadi konsekuensi logis dalam kontestasi politik baik dilevel nasional bahkan didaerah sekalipun.

Panggung politik menuntut calon yang diusung untuk mendapatkan simpati publik. Simpati publik yang dimaksud adalah wujud dari persepsi positif yang sejatinya sudah dibangun oleh kandidat jauh sebelum masa kampanye dilakukan. Dan proses pembentukan opini publik ini disebut dengan kegiatan personal branding. Personal branding merupakan akar pada proses pembentukan citra, dan personal branding adalah modal awal dalam konsep political public relations.

Konsep Political Public Relation berorientasi pada bagaimana membangun citra. Persepsi publik diarahkan kepada gambaran umum yang melekat pada organisasi atau partainya, dan praktek PR menjadi tolak ukur konkret dalam usaha mendapatkan perhatian publik yang berimplikasi pada pemenangan kontestasi politik. Sebagai partai baru dengan kader-kader nya sebagai politisi pemula, maka partai PSI sangat membutuhkan kegiatan-kegiatan public relations dalam usaha membangun citra guna merebut perhatian publik, sehingga kegiatan-kegiatan public relations dalam bentuk marketing politic dan political branding menjadi langkah konkret yang harus dilakukan dalam menghadapi kontestasi politik tahun 2019, bukan hanya diskala nasional namun juga kepada para calon legislatif didaerah. Dengan demikian, sangat relevan jika penelitian ini ingin mengelaborasi bagaimana public relations mengambil peran dalam politik praktis.

Penelitian ini penting dilakukan karena mengkaji politik praktis didaerah sebagai objek penelitian yang selama ini luput dari perhatian. Melihat politik praktis dari perspektif public relations adalah sesuatu yang baru dan menarik karena dalam prakteknya PR Politik telah lama dilakukan, namun mengeksplorasinya dalam bentuk kajian ilmiah merupakan suatu tantangan baru dalam konteks penelitian komunikasi. Tujuan jangka panjang penelitian ini adalah sebagai sumbangan keilmuan dan sebagai referensi kajian public relations. Pada tataran praktis, penelitian ini diharapkan mampu memberikan wacana keilmuan pada partai politik maupun politisi bahwa public relations merupakan aspek penting yang bisa diperhitungkan dalam dinamika politik hari ini.

\section{B. METODE}

Penelitian ini menggunakan metode studi kasus. Studi kasus merupakan strategi penelitian dimana didalamnya peneliti menyelidiki secara cermat suatu program, peristiwa, aktivitas, proses atau kelompok individu. Dengan metode ini peneliti mengumpulkan informasi secara lengkap dengan menggunakan berbagai prosedur pengumpulan data berdasarkan waktu yang telah ditentukan (Creswell, 2009). Penelitian ini mengarah kepada jenis studi kasus intrinsik (intrinsic case study), yaitu jenis penelitian studi kasus yang dilakukan untuk mengenali dan mempelajari kasus secara lebih. Studi kasus jenis ini mengharuskan peneliti mengabaikan perkara lain agar lebih fokus dan mampu memunculkan sesuatu yang baru dalam penelitiannya (Denzin, 2011). Dalam penelitian ini, peneliti mengamati strategi political public relations yang dilakukan politisi pemula kader Partai Solidaritas Indonesia wilayah Riau pada pemilihan legislatif tahun 2019. Tipe penelitian ini adalah deskriptif kualitatif, peneliti mengelaborasi proses implementasi political public relations selama pemilihan legislatif tahun 2019. Penelitian dengan metode observasi (pengamatan) dilakukan pada masa pra kampanye dan berlanjut pada masa kampanye, pemilihan hingga pasca pemilihan. Pengambilan data melalui metode wawancara dan dokumentasi penelitian dilakukan pada saat masa kampanye, hari pemilihan hingga pasca pemilihan. 


\section{PEMBAHASAN}

Konsep Political Public Relations merupakan bagian dari kegiatan public relations dalam usaha membangun komunikasi kepada khalayak internal maupun eksternal dalam konteks politik. Kegiatan ini dilakukan secara sistematis, terencana dan terarah. Tujuannya adalah untuk mendapatkan kesepahaman atau mutual understanding dengan berbagai pihak dalam upaya mewujudkan tujuan politik dari sebuah organisasi (Heryanto, 2012).

McNair (2011) mengidentifikasi 4 bentuk keiatan PR politik, dintaranya : manajemen media, manajemen citra, manajemen komunikasi dan manajemen informasi. Manajemen media dilakukan dengan membuat berbagai kegiatan partai yang bisa diliput oleh media. Keigatan yang dimaksud hendaknya memiliki nilai berita dari perspektif media massa. Sehingga kebutuhan media untuk pemberitaan dapat terpenuhi. Dengan demikian, secara otomatis politisi atau partai politik telah melakukan publisitas tanpa mengeluarkan biaya yang besar. Manajemen citra dilakukan dengan ikut serta dalam kegiatan-kegiatan sosial. Politisi atau partai politik diharapkan selalu terlibat aktif dalam berbagai keiatan sosial di masyaakat, terlebih dilingkungan masyarakat konstituennya. Dengan demikian citra positif akan tebentuk dan terjaga dengan sendirinya. Manajemen komunikasi dilakukan dengan mengorganisir pola komunikasi baik di internal organisasi atau ke eksternal organisasi. Diantaranya adalah dengan menetapkan saluran komunikasi dan mengontrol pesan komunikasi politik dari oranisasi. Dan terakhir adalah manajemen informasi. Informasi dilingkungan organisasi politik hendaknya selalu mendapatkan pengawasan dari elit partai politik, karena informasi yang tersebar akan berdampak langsung pada opini yang terbentuk, dan opini akan sangat berpengaruh kepada agenda politik lainnya.

Secara terminoloi, political public relations dengan public relations memiliki beberapa perbedaan :

Tabel 1 : perbedaan political public relations dengan public relations

\begin{tabular}{|l|l|l|}
\hline Aspek Pembeda & Public Relations & Political Public Relations \\
\hline Tujuan komunikasi & Bisnis, komersil & $\begin{array}{l}\text { Bertujuan politis, kepentingan } \\
\text { organisasi atau partai }\end{array}$ \\
\hline Aktor komunikasi & Tenaga PR Profesional & Semua aktor politik \\
\hline Media komunikasi & $\begin{array}{l}\text { Publisitas, media informasi } \\
\text { publik }\end{array}$ & $\begin{array}{l}\text { Media mainstream dan media } \\
\text { sosial }\end{array}$ \\
\hline Output & $\begin{array}{l}\text { Reputasi menjadi aset } \\
\text { utama }\end{array}$ & Relationsip setara dengan reputasi \\
\hline
\end{tabular}

Sumber : Stromback dan Kiousis (2013)

Agenda PR Politik merujuk kepada agenda partai politik. Konsep-konsep PR politik disusun dan direncanakan menyesuaikan dengan rencana oranisasi atau partai politik. PR politik mengharuskan aktor politik (politisi) memiliki karakter dan ketokohan dalam aspek kebijakan dan sosial, dengan demikian pekerjaan PR politik akan lebih mudah untuk dikondisikan guna menaikkan angka elektabilitas kandidat. Personal branding seorang calon menjadi kunci dalam usaha political branding dalam konsep political public relations. Artinya aktor politik dituntut untuk mampu melakukan image building (membangun citra) terhadap konstiutennya karena itu adalah modal dalam kontestasi politik. Branding diri ini bisa terbentuk dari integritas aktor politik, kepekaan sosial, serta pemahaman kandidat terhadap persoalan daerah pemilihannya. Dalam perspektif bisnis, modal sosial inilah yang akan memberi pengaruh besar terhadap "keputusan membeli" konstituen pada masa pemilihan umum.

Berdasarkan temuan penelitian dilapangan, terdapat beberapa langkah strategis merujuk kepada konsep political public relations yang dilakukan oleh partai PSI Riau dalam usaha menghadapi pemilihan legislatif pada tahun 2019, diantaranya adalah pembentukan citra (image building), political branding dan marketing politic. 


\section{Pembentukan Citra Politik (image building)}

Kontestasi politik menuntut kandidat politik untuk memiliki citra yang baik dihadapan konstituennya. Citra positif lahir dari proses pembentukan citra yang terstruktur, sistematis, dan masiv. Citra juga disebut sebagai image (gambar), penggambaran atau penilaian publik teradap sesuatu hal. Jika dihubunkan dengan konsep PR politik, maka citra menjadi suatu keniscayaan yang mutlak dimiliki oleh seorang calon atau kandidat politik (Stromback, 2013).

Pembentukan citra politik biasanya mengacu kepada peran politik kandidat (political role) dan gaya politik kandidat (political stylistic). Dalam al ini, politisi kandidat partai PSI menunjukkan perannya untuk memenuhi ekspekktasi publik. Peran disini berkaitan juga dengan kualifikasi kandidat serta track record atau rekam jejaknya. Peran ini juga bisa dimunculkan dengan ide-ide berupa solusi kebijakan yang akan diambil ketika telah mendapat kursi dilegislatif nanti. Peran kandidat partai PSI selalu dimunculkan selama masa sosialisasi dan masa kampanye dilakukan dengan berdialog langsung kepada konstituennya. Sedangkan gaya politik kandidat (political stylistic) menjadi kunci dalam proses pembentukan citra. Gaya politik kandidat ini sangat dekat kaitannya dengan karakter individu. Mulai dari gaya bicara, gaya mendengar aspirasi, hingga pada gaya bersosialisasi (sikap). Political stylistic ini menjadi faktor penentu dalam proses pembentukan citra karena pesan visual akan menanamkan nilai individu kepada calon pemilihnya. Ilyas (2010) mengatakan bawa political stylistic adalah cara calon atau kandidat menampilkan dirinya untuk memberi kesan kepada konstituen. Dalam perspektif PR politik, proses pembentukn citra ini hendaknya dibarengi dengan perencanaan komunikasi yang baik yaitu dengan melibatkan peran media massa.

Pembentukan citra (image building) dalam kontestasi politik 2019 ini juga marak dilakukan melalui media sosial. Perkembangan teknologi komunikasi berbasis internet memungkinkan seluruh penggunanya untuk melakukan berbagai bentuk komunikasi dengan jangkauan yang sangat luas. Hal ini menjadi pilihan alternatif partai PSI Riau dan calegnya untuk menyampaikan pesan-pesan ideloginya kepada calon pemilihnya. Kondisi ini membawa kandidat melakukan kampanye murah melalui sosial media. Kampanye melalui sosial media dirasa cukup efektif dan efisien dalam pengelolaan informasi politik.

\section{Gambar 1 : Konten sosial media salah satu calon legislatif Riau}
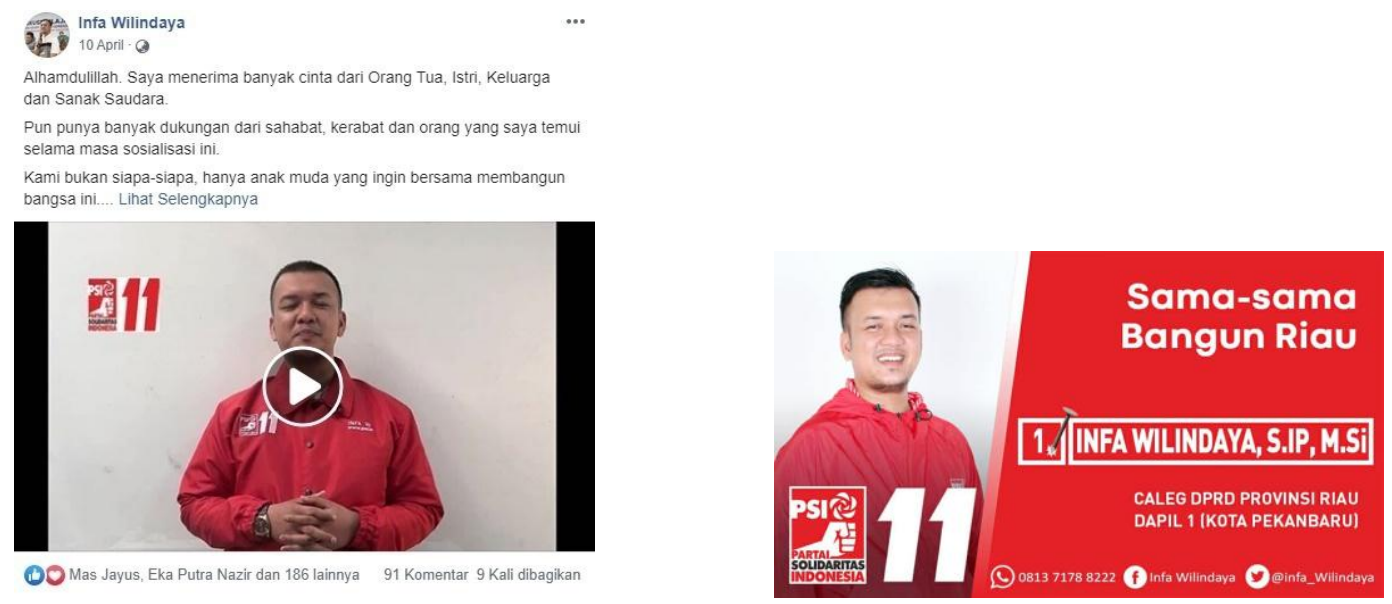

Sumber : dokumen pribadi dari akun facebook Infa Wilindaya

Kekuatan media sosial dalam mempengaruhi masyarakat terdapat pada aspek sosialnya, dimana secara ekslusif terjadi interaksi dan partisipasi. Artinya, opini dapat digulirkan oleh kolega, teman atau relasi lain yang dapat mengkonsolidasikan kepentingan yang dapat mempengaruhi atau melemahkan pendapat (Social media : The New Power Of Political Influence Version 1.O Ari-Matti Auvinen Centre for European Studies).

Memaksimalkan penggunaan sosial media rupanya merupakan strategi yang tepat dalam mengendalikan opini publik. Melalui sosial media merupakan cara terbaik dalam membentuk opini 
publik karena mayoritas pemilih telah menggunakan sosial media. Untuk itu, menjadi keharusan bagi aktor politik untuk dapat melakukan adaptasi dengan melakukan persuasi kepada para calon konstituennya melalui sosial media dalam rangka pembentukan citra. Salah satu model komunikasi yang bisa dilakukan ialah dengan model two ways communication, dimana ada percakapan dua arah dari aktor politik dengan konstituennya. Model ini akan menciptakan hubungan yang setara dan interaktif antara aktor politik dan publiknya (Indrayani, 2009).

\section{Political Branding}

Secara etimologi, branding berasal dari kata brand (merek). Sehingga secara sederhana branding dapat diartikan sebagai usaha dalam pemberian merek terhadap suatu produk yang bertujuan memberi kesan kepada konsumen. Branding dapat dilakukan berupa nama, tanda, simbol, desain, kombinasi dan lain-lain yang mencirikan identitas tertentu. Brand juga dapat diartikan sebagai seperangkat pengetahuan konsumen terhadap sebuah produk atau jasa sebuah lembaga. Dalam dunia politik, branding sepertinya selalu dikaitkan sebagai sebuah upaya pencitraan atau pembenetukan image kepada sebuah partai atau personal kandidat. Bagi penulis, branding politik dapat diartikan sebagai seluruh pengalaman dan aktivitas politik yang dikemas dengan format informasi yang terstruktur sehingga dapat dimaknai bersama sebagai upaya positif organisasi politik atau kandidat. Branding politik dapat membentuk persepsi positif yang mampu mempenngaruhi keyakinan dan sikap politik masyarakat. Branding politik berkaitan dengan hal-hal detail dalam pelaksanaan kegiatan politik. Dalam proses membangun branding politik yang baik adalah dengan mendesain pesan politik sebaik mungkin, jelas dan komunikatif. Sehingga kesepepakatan pemahaman bersama dapat dicapai dan missed understanding pada pemaknaan pesan dapat ditekan. Disisi yang lain, komunikator dalam branding politik haruslah orang yang memahami betul karakter, kebutuhan dan keinginan konsumen (publik). Harapannya, branding yang dilakukan memiliki nilai yang bukan hanya sekedar kepentingan politis (Wasesa, 2011). Setidaknya terdapat lima tahap strategis branding politik yang telah dilakukan caleg PSI Riau dalam menghadapi pemimlihan legislatif tahun 2019.

Tabel 2 : Tahapan Strategi Branding Politik PSI Riau

\begin{tabular}{|l|l|l|}
\hline TAHAPAN & $\begin{array}{l}\text { STRATEGIS } \\
\text { BRANDING } \\
\text { POLITIK }\end{array}$ & \multicolumn{1}{c|}{ UNSUR CAPAIAN } \\
\hline Tahap 1 & $\begin{array}{l}\text { Brand } \\
\text { Awareness }\end{array}$ & $\begin{array}{l}\text { Pada tahap ini caleg PSI Riau memperkenalkan diri kepada calon } \\
\text { pemilih yan kemudian calon pemili menyadari akan keberadaan } \\
\text { calon leislatif PSI yan diusun, artinya keberadaan cale betulbetul } \\
\text { diketaui secara sadar. }\end{array}$ \\
\hline Tahap 2 & $\begin{array}{l}\text { Brand } \\
\text { Knowledge }\end{array}$ & $\begin{array}{l}\text { Pada tahap ini calon pemilih sudah mulai punya pengetahuan dan } \\
\text { pemahaman lebih tentan caleg dari PSI Riau. Artinya, tahap ini } \\
\text { adalah taap dimana pemilih sudah tahu akan eksistensi kandidat } \\
\text { sekaligus mulai memahami maksud politik dan program kandidat. }\end{array}$ \\
\hline Tahap 3 & $\begin{array}{l}\text { Brand } \\
\text { Preference }\end{array}$ & $\begin{array}{l}\text { Pada tahap ini calon pemilih sudah mulai membandingkan antara } \\
\text { caleg PSI Riau dengan kandidat yang lain dengan memberikan } \\
\text { persepsi yang positif kepada caleg PSI Riau dibanding kepada } \\
\text { kandidat lain. Tahap ini sekaligus menunjukan tingkat } \\
\text { keberhasilan positioning yang dilakukan kandidat PSI. }\end{array}$ \\
\hline Tahap 4 & Brand Liking & $\begin{array}{l}\text { Pada tahap ini calon pemilih mulai memiliki rasa suka terhadap } \\
\text { caleg PSI Riau dan berniat akan memilihnya pada saat pemilihan. } \\
\text { Jika seorang kandidat sudah memasuki tahap ini dan memperoleh } \\
\text { hasilnya, maka dapat dibilang posisinya sudah memasuki wilayah } \\
\text { aman tahap satu. Namun yang mesti diingat, rasa suka seseorang } \\
\text { masih bisa dipengaruhi bahkan dirubah dengan berbagai kondisi }\end{array}$ \\
\hline
\end{tabular}




\begin{tabular}{|l|l|l|}
\hline & & yang datang kemudian \\
\hline Tahap 5 & Brand Loyalty & $\begin{array}{l}\text { Pada tahap ini calon pemilih sudah setia kepada kandidat yang } \\
\text { akan dipilihnya. Pemilih sudah memiliki keyakinan yang kuat } \\
\text { untuk mendukung dan memilih kandidat dan tidak akan memilih } \\
\text { kandidat lain. }\end{array}$ \\
\hline
\end{tabular}

Sumber : Analisis peneliti

\section{Implementasi Marketing politic}

Marketing adalah konsep yang menghubungkan antara produsen dan konsumen. Lebih lanjut, Menurut Bagozzi (1975), marketing adalah proses yang memungkinkan adanya pertukaran (exchange) antara dua pihak atau lebih. Konsep marketing selalu dikaitkan dengan institusi bisnis yang berorientasi profit, namun saat ini konsep marketing juga digunakan oleh institusi sosial dan bahkan telah masuk pada ranah politik.

Jika dalam konteks bisnis marketing dikaitkan dengan bentuk komunikasi dalam pelayanan kepada konsumen dengan tujuan mempengaruhi agar konsumen memutuskan untuk membeli. Sementara dalam politik, kandidat melakukan kampanye, memberi janji, kebaikan, pilihan kebijakan, konstribusi yang itu semua adalah citra yang tawarkan oleh kandidat kepada pemilih(Kotler, 2010). Marketing memiliki peran penting bagi institusi politik. Tujuan dari marketing dalam politik adalah untuk membantu partai politik atau kandidat untuk menjadi lebih dikenal konstituennya. Lebih lanjut marketing politic mengambil peran sebagai metode perantara antara kandidat dan program yang akan diusung dengan peenggunaan komunikasi politik yang baik. Konsep marketing dalam politik memudahkan kandidat agar lebih dekat dengan publik calon pemilihnya, sehingga marketing politic mampu merubah pola perilaku pemililh (Butler dan Collins), dengan demikian marketing politic menjadi penting untuk dilakukan (Firmanzah, 2008).

Dalam pelaksanaanya, marketing politic selalu mengacu kepada dua hal yaitu struktur dan proses. Struktur marketing politic meliputi produk, organisasi dan pasar. Produk dalam hal ini dapat dimaknai sebagai orang/ideologi (person/ideologi). Poin orang/ideologi adalah hal yang berkaitan dengan kompetensi, rekam jejak serta rencana masa depan. Kandidat tertentu dengan latar belakang ideologi yang tertentu akan sangat berpengaruh kepada calon pemilihnya. Hal ini disebabkan bahwa karakter pemilih hari ini telah memiliki banyak sumber informasi untuk mendapatkan pemahaman yang cukup tentang kandidat seorang calon. PSI dengan membawa nama baru dengan sogan bukan partai rongsokan yakin bahwa calon/kandidat yang mereka usung merupakan kandidat yang memiliki karakter dan semanngat baru untuk menjadi calon legislatif. Hal selanjutnya adalah organisasi. Organisasi merupakan kendaraan politik bagi seorang kandidat. Oleh karena itu, seorang kandidat haruslah mengetahui lebih jauh bagaimana latar belakang organisasi tersebut. Bagi PSI Riau, sistem kaderisasi menjadi penting dilakukan sebelum meloloskannya sebagai calon yang diusung. Dan hal terakhir adalah pasar.

Dinamika dan persainan panun politik menuntut caleg PSI Riau untuk memahami pasar politik. Diantaranya ialah bagaimana kondisi sosial, tingkat pendidikan, minat politik, serta pengalaman politik sebelumnya. Selain itu, kandidat juga dituntut untuk menguasai secara menyeluruh hal-hal yang berkaitan dengan regulasi pemilihan umum. Mulai dari masa pencalonan, aturan teknis sosialisasi dan kampanye, hingga hal-hal administrasi lainnya.

Pada dasarnya marketing politic memiliki jangkauan yang cukup luas, sehingga konsep ini tidak bisa dibatasi pada penerapan marketing saja. Namun juga harus bisa menyentuh budaya politik, pendidikan, ekonomi dan isu krusial lain yang bisa mempengaruhi persepsi politik. Dalam aktifitas marketing, pesan caleg PSI Riau bisa saja dikemas semenarik mungkin. Konsumen politik (pemilih) bisa saja hanya diberikan informasi dari satu sisi demi mencapai tujuan keuntungan politis. Sehingga prakteknya, caleg PSI Riau haruslah terlihat menarik bagi calon pemilihnya. Untuk itu partai PSI Riau telah membekali para calon kandidat yang diusung dengan seperangkat pengetahuan tentang permasalahan wilayah Riau sebagai daerah pemilihannya. Selain itu, standar kemampuan 
berkomunikasi juga menjadi poin penting lainnya yang harus dikuasai oleh caleg PSI Riau agar pola komunikasi terjadi dua arah. Hal lain yang dipertimbangkan PSI Riau adalah peranan media, baik itu media massa maupun media sosial. Media cukup besar memberi pengaruh terhadap keberhasilan kandidat dalam pemilihan. PSI Riau meyakini bahwa media berfungsi sebagai sarana informasi dan pendidikan politik. Jika media tidak tepat dalam membungkus informasi tentang caleg PSI Riau maka akan besar berpengaruh terhadap keberhasilan pemilihan caleg tersebut. Untuk itu, partai PSI bekerjasama dengan media dalam menyamakan perspektif termasuk juga dalam menentukan fomat pesan-pesan politiknya.

Akhirnya, implementasi marketing politic telah diupayakan secara menyeluruh. Artinya, pelaksanaan marketing politic telah diterapkan secara benar, detail dan terstruktur sebagai sebuah langkah dalam kontestasi politik. PSI Riau meyakini bahwa penerapan marketing politic akan berdampak langsung pada pembentukan citra partai PSI Riau dan calegnya, sehingga proses marketing politic menjadi investasi politik yang berimplikasi jangka panjang. Prinsipnya, eksistensi partai politik atau kandidat akan dipengaruhi oleh seberapa maksimal penerapan marketing politic dilakukan. Mengingat kontestasi politik yang semakin tinggi, maka marketing politic PSI Riau diperkuat dengan konsep branding. Branding berusaha memberikan karakteristik tersendiri pada ikon politik. Brand tersebut berupa karakteristik identitas caleg dan partainya, hal ini mencakup nama, tagline, dan lain-lain yang mencirikan partai dan kandidatnya. Branding sengaja dibuat guna mendapatkan positioning didepan khalayak calon pemilih dalam pasar politik.

\section{KESIMPULAN}

Aktifitas political public relations merupakan langkah strategis yang memberi dampak langsung pada masa pemilihan umum. Usaha political public relations dilakukan dalam rangka membentuk persepsi positif publik terhadap partai atau kandidat. Politisi Partai Solidaritas Indonesia (PSI) wilayah Riau menyadari sepenuhnya bahwa langkah ini harus dilakukan mengingat partai PSI merupakan partai baru dengan para calon/kandidat legislatifnya sebagai politisi pemula. Langkah yang telah dilakukan adalah dengan melakukan membangun citra (image building), branding politik (political branding) dan pemasaran politik (marketing politic). Aktifitas political public relations yang dilakukan kandidat partai PSI Riau adalah dengan turun langsung bersosiaslisasi dengan calon konstituennya. Menyampaikan ide dan gagasan sehingga konstituen mengenal pribadi caleg PSI dan arah kebijakan yang ditawarkan, dengan demikian langkah untuk pembentukan citra telah dilakukan. Selanjutnya kegiatan branding politik dilakukan dengan mendesain positioning didepan khalayak calon pemilih dengan memaksimalkan penggunaan sosial media. Dan langkah terakhir adalah dengan melakukan implementasi pemasaran politik (marketing politic).

\section{DAFTAR PUSTAKA}

Budiardjo, Miriam. 2008. Dasar-Dasar Ilmu Politik (Edisi Revisi). Jakarta : Gramedia Pustaka Utama.

Heryanto, Gun Gun \& Irwa Zarkasy. 2012. Public Relations Politik.Jakarta : Ghalia Indonesia.

McNair, B. 2011. An Introduction of Political Communication. New York : Routledge

Stromback, J \& Kiousis, S. 2013. Political Public Relations : Principles and Applications. New York : Routledge.

Creswell, John. 2009. Research Design (Pendekatan Kualitatif, Kuantitatif dan Campuran). Yogyakarta : Pustaka Palajar

Denzin, Norman K. \& Yvona S, Lincoln. 2011. Handbook of Qualitative Research. Yogyakarta : Pustaka Pelajar

Philip and Neil Kotler. 2010. "Political Marketing; Generating Effective Candidates, Campaigns, and Causes", in Handbook of Political Marketing, ed Bruce I. NewmanThousand Oaks, CA: SAGE Publications, Inc.,3-18,6

Firmanzah. 2008. Marketing politic : Antara Pemahaman dan Realitas. Jakarta: Yayasan Obor Indonesia

Ilyas Sampe. 2010. Konsep Dan Aplikasi Public Relations Politik Pada Kontestasi Politik Di Era Demokrasi. Palu : Jurnal Academica Fisip Untad Vol. 2 No. 02 (Oktober) 2010 
Indrayani, I.I. 2009. Media dan Politik Citra Dalam Politik Indonesia Kontemporer. Scriptura.

Umar Farouk. 2014. Implementasi Political public relations Dalam Pilihan Presiden (Pilpres) 2014.

Semarang. Jurnal Admisi dan Bisnis, Volume 15 Nomor 3 Oktober 2014

Wasesa, Silih A. 2011. Political Branding \& Public Relations. Jakarta : Gramedia

Undang-Undang Nomor 7 Tahun 2007 tentang Pemilihan Umum

Robby. 2010. Branding Politik. https://teorimp.wordpress.com/2010/12/28/branding-politik/ (diakses pada 26 september 2019 pukul 11.00) 